\title{
Blended Learning in Pronunciation Classroom for Higher Education: Students' Perception
}

\author{
${ }^{1}$ Tiara Al-Fisyar, ${ }^{2}$ Sukma Nur Ardini, and ${ }^{3}$ Dyah Nugrahani \\ 1,2,3 Universitas PGRI Semarang \\ (sukmanurardini@upgris.ac.id)
}

Article History: Submitted December 30 ${ }^{\text {th }}, 2020$; Accepted February 22 $2^{\text {nd }}, 2021$; Published 24 February 2021

\begin{abstract}
With skyrocketing development of online learning due to the Covid-19 outbreak, pronunciation classroom is one of the evidences that was quite affected by this pandemic situation. The controversial mindset, that this lesson needs literally face-to-face practices since they relate to organ speech's output, leads the authors into this investigation. This paper was aimed at finding out students' response toward the implementation of blended learning in pronunciation classrooms. The research design was descriptive quantitative with the population of 176 fourth semester students of English Education Department of Universitas PGRI Semarang in the academic year of 2019/2020, and 28 students coming from 4A to 4D were taken as the sample. The data were collected online through Google Form using a perception questionnaire and confirmed by phone call interview preceded by classroom observation. The data from the questionnaire were then analyzed quantitatively to determine the level of students' perception supported by descriptive data from the interviews. The results indicated that students' perception toward blended learning in the Pronunciation classroom was in the level of intermediate. Additionally, the interview revealed that the students were satisfied with blended learning implementation in Pronunciation classroom. They preferred online classes which were balanced in terms of assignment-giving and learning material. Too many assignments with fewer materials only burden the students. Therefore, the lecturers were suggested to consider their ability in handling the class, which also interests students in engaging the online classes more.
\end{abstract}

Keywords: blended learning; pronunciation, higher education, students' perception

Abstrak. Pesatnya perkembangan pembelajaran online akibat dari wabah Covid, kelas pronunciation sebagai salah satu bukti yang cukup terpengaruh oleh situasi pandemi ini. Pola pikir kontroversi, bahwa pelajaran pronunciation benar-benar membutuhkan praktik tatap muka karena berkaitan dengan luaran speech organs, sehingga mengarahkan peneliti ke permasalahan ini. Penelitian ini bertujuan untuk mengetahui respons mahasiswa terhadap penerapan blended learning di kelas pronunciation. Desain penelitian adalah deskriptif kuantitatif dengan populasi 176 mahasiswa semester IV Jurusan Pendidikan Bahasa Inggris Universitas PGRI Semarang tahun ajaran 2019/2020 dan diambil sampel 28 mahasiswa dari $4 A$ sampai $4 D$. Pengumpulan data dilakukan secara online melalui google form menggunakan kuesioner persepsi dan dikonfirmasi dengan wawancara melalui telepon yang didahului dengan observasi kelas. Data dari kuesioner dianalisis secara kuantitatf didukung oleh data interview yang dianalisis secara deskriptif. Hasil penelitian ini menunjukkan bahwa persepsi mahasiswa terhadap blended learning di kelas pronunciation berada pada level intermediate. Selain itu, hasil wawancara menunjukkan bahwa mahasiswa merasa puas dengan penerapan blended learning di kelas pronunciation. Mereka lebih menyukai kelas online yang seimbang dalam hal pemberian tugas dan materi pembelajaran. Terlalu banyak tugas dengan materi yang lebih sedikit hanya akan membebani mahasiswa. Oleh karena itu, para dosen disarankan untuk mempertimbangkan kemampuannya dalam menangani perkuliahan yang juga menarik minat mahasiswa untuk lebih banyak terlibat dalam kelas online.

Kata kunci: blended learning; pronunciation, pendidikan tinggi, persepsi mahasiswa 


\section{INTRODUCTION}

With skyrocketing development of online learning due to the Covid outbreak that initially attacked Tiongkok on December 2019, it began to spread out in almost all countries in March 2020. As Covid-19's status became a pandemic, various sectors began to be affected. Besides health, other sectors such as economy, industry, trade, tourism, and education were also affected. In the education sector, the most significant change that occurs after the pandemic is the temporary dismissal of face-to-face teaching-learning processes for schools at all levels, which is then replaced by the application of learning from home systems, or what is referred to Pembelajaran Jarak Jauh (PJJ) or Distance Learning (DL).

The distance learning system makes students and teachers inevitably have to do the learning process online to break the chain of transmission from the virus itself. Even though there were a lot of disagreement, the current Minister of Education and Culture of the Republic of Indonesia, Nadiem Makarim, assured all people about the period of adaptation that we are going through for now, where all parties are demanded to learn and adapt in order to create a better situation (www.medcom.id). Facing the situation described above, educators must provide the best education atmosphere for students to choose the right learning method.

Some methods can be implemented during this distance learning period; one of the most known methods is blended learning. Blended learning is a face-to-face learning (conventional) method accompanied by online learning; it is often defined as the combination of face-to-face and online learning (Akyol \& Garrison, 2011). A blended learning environment is a flexible approach, which combines traditional face-to-face instruction with computer-mediated or online instruction (Bonk \& Graham, 2012; Gecer, 2013; Graham, 2013; Bueno \& Lopez, 2014). With this statement, learning activities can be carried out anywhere and anytime. Until now, blended learning can be done online through the internet in education platforms, applications, etc.

Until this paper is being written, several applications are used by students and lecturers in conducting the online classes, such as Zoom, Google Meet, Jitsi, Discord, WhatsApp, YouTube, and so on. Some applications like Zoom, Google Meet and Jitsi allow students to interact with their fellow and lecturers face-to-face through video conference, making the instructional process more interesting, for they can have a class wherever they are, as long as they have their gadgets with them. This way, the students do not only follow the teaching and learning activity inside the classroom, but they can also join the informal chatting group outside the classroom. This also can give them more exposure and more intensity of language practice. As a model which is considered to be more flexible than the conventional one, blended learning demands lecturer to make his teaching method as interesting as possible to engage his students more. To create an interesting learning environment, a lecturer should apply creative teaching techniques and an interactive learning model.

There are still certain subjects that are quite difficult to carry out online for several reasons, among them are subjects that require laboratory practice and subjects that require literally face-to-face practices. As a field of science that requires many practices compared to theories, pronunciation is a subject that is immensely affected by this pandemic situation where face-to-face practices need to be done through online learning. According to Gilakjani (2012), one of the key requirements for language proficiency is to secure understandable pronunciation for the language learners. Therefore, pronunciation subject is crucial for a language learner, otherwise, miscommunication will be occurred. In general terms, pronunciation itself can be defined as the production of important sound in two senses. Kelly 
(2000) stated that pronunciation is the ability to use the correct stress, rhythm, and intonation of a word in a spoken language. Those elements are extremely difficult for English as a Foreign Language (EFL) Learners, especially Javanese, since there are way differences between English and Javanese sound system. Senowarsito \& Ardini (2019) found that cognitive on their first language will interfere with their pronunciation of foreign language words or phrases. Their research found that Javanese adult students had problems pronouncing the word <the>. They tended to pronounce [(n)də] for the word <the > with the phoneme $/ \mathrm{n} /$ that precedes [ðə], instead of [ðə] alone. In other words, pronunciation in formal education requires practice and guidance from lecturers during the process.

According to Gilakjani (2012), in learning pronunciation, learners must also become part of the learning process, actively involved in their learning. Furthermore, he stresses that lecturers must be more active in supporting students so that the learning process is more optimally done. With the instructor acting as a 'speech coach' rather than a mere pronunciation checker, feedbacks will inspire students to improve their pronunciation. Which, of course, this relationship between teachers and students becomes even more difficult to build during this pandemic, where both cannot meet face-to-face. Hence, to get around this, the application of an appropriate learning model becomes very important for the achievement of satisfying learning processes and results. The right application's existence is also very important, considering that students' self-motivation is one of the determining factors for student learning success. This is supported by research from Ardini et al. (2016) who stated that one of the reasons for the problems in the pronunciation of the fifth semester students of the English study program at Universitas PGRI Semarang is the internal factor, which is from students themselves, whose self-motivation and intention to explore phonetic symbols is low.

On the other hand, some studies discussing about the perception, the effectiveness, and the challenges of using blended learning were found (Yoon, 2010; Bonk \& Graham, 2012; Albiladi \& Alshareef, 2019). They identified six major issues dealing with a blended learning environment. These issues are the role of live interaction, the role of learners' choices and self-regulation, models for support and training, dealing with the digital divide, cultural adaptation, and finding balance between innovation and production. Nevertheless, there was no study discussing about pronunciation classroom where learners must be actively involved in their learning in pronunciation classroom (Gilakjani, 2012). With the enactment of the rules of distance learning and this blended learning, students' ability in pronunciation will indirectly be affected as well, given the changing pattern of transfer of knowledge, from the previous face-to-face offline learning process to online. This underlies the researchers in making this paper, to find out students' perception of blended learning implementation in Pronunciation classroom in Universitas PGRI Semarang.

\section{METHOD}

The site of this research was in Universitas PGRI Semarang, specifically Pronunciation classes of English Education Department. The population of the study was 176 students coming from the 4th semester students who took Pronunciation subject in the academic year 2019/2020. The sample of the research was 28 students who were chosen using the purposive sampling technique.

It was a descriptive quantitative research design since the data of the research served in the form of numbers supported by descriptive data. As Ary (2010:22) declared that quantitative 
research uses objective measurement to gather numeric data that are used to answer question or test predetermined hypotheses. The percentage shown in this research was to display the perception levels which were then interpreted using words.

Perception questionnaires and interview guidelines were used to obtain the data. A questionnaire is basically a set of questions related to some topics that have to be fulfilled by the research object to get the data. A questionnaire consists of a number of questions printed or typed in a definite order on a form or set of forms (Kothari, 2004). In this study, the researchers tended to use the closed-ended questionnaire to limit the scope of the research. Closed-ended questionnaire is the closed question or the questionnaire which the respondents need to put their answer in the questionnaire with yes or no answer (Sukardi, 2003:77). The questionnaire was about statements to find out students' perception of blended learning model implementation in Pronunciation classroom. There were 20 items of Likert scale with 5 options of strongly agree, agree, undecided, disagree, and strongly disagree were distributed through Google Form and were automatically transcript into excel form. The second instrument used in this study was interview guideline. Harvey \& Knight (1996:14) remarks an interview as an interchange of views between two or more people on a topic of mutual interest, sees the centrality of human interaction for knowledge production, and emphasizes the social situatedness of research data. The interview that has been given by the researchers to the respondents was the semi-interview, which was an informal interview. The interviews were done using phone calls. The aim was to support and clarify answers about students' perception of blended learning implementation which were done initially using questionnaire.

The data in this research were obtained from questionnaire and interview, which were preceded by class observation. In distributing the instruments, the researchers handed out the questionnaires online, as the following stages: firstly, the researchers set the questionnaire in the form of Google Form, then distributed the link into WhatsApp group. After that, the researchers calculated the percentage levels by measuring the mean score of each item to obtain the research objective. This paper adopted the implementation of the mean score as shown in Table 1 below.

Table 1 The implementation of the mean score

\begin{tabular}{|c|c|c|}
\hline No & Mean Score & Interpretation \\
\hline 1. & $1.00-1.80$ & Very low \\
\hline 2. & $1.81-2.60$ & Low \\
\hline 3. & $2.61-3.40$ & Medium \\
\hline 4. & $3.41-4.20$ & High \\
\hline 5. & $4.21-5.00$ & Very High \\
\hline
\end{tabular}

Later on, the researchers did phone call interviews where each respondent was confirmed regarding their questionnaire answers. At last, the researchers interpreted the data using the descriptive method. 


\section{RESULTS AND DISCUSSION}

\section{Perception Questionnaire Results}

To collect the data regarding students' perception of blended learning in Pronunciation classroom, the researchers had distributed questionnaires and conducted interviews to the respondents. The results of the questionnaire would reveal the level of students' perception in the implementation of blended learning in pronunciation classroom. There were 20 Likert scale items with 5 options of strongly agree, agree, undecided, disagree, and strongly disagree. The results will be described in detail as follows.

Statement number 1 was about how students understand the concept of blended learning. The results showed that $3 \%$ of the students strongly agreed with the statement, $46 \%$ of them were agree, $36 \%$ were undecided, $11 \%$ were disagree, and $4 \%$ strongly disagreed. The mean score of statement number 1 was 3.4, it was categorized as medium level.

Statement number 2 was to find out how students are used to study independently. The results displayed that $13 \%$ of the students strongly agreed with the statement, $29 \%$ of them were agree, $32 \%$ were undecided, $26 \%$ were disagree, and $0 \%$ strongly disagreed. The mean score of statement number 2 was 3.4 which categorized as medium level.

Statement number 3 was to find out how the students are disciplined persons. The results revealed that $14 \%$ of the students strongly agreed with the statement, $46 \%$ of them were agree, $18 \%$ of them were undecided, $18 \%$ of them were disagree, and $4 \%$ strongly disagree. The mean score of statement number 3 was 3.5 which categorized as high level.

Statement number 4 was to find out how the students feel comfortable when they do not need to go to campus too often. The results showed that $11 \%$ of the students strongly agreed with the statement, $18 \%$ of them agreed, $25 \%$ of them were undecided, $21 \%$ of them disagree, and $25 \%$ strongly disagreed. The mean score of statement number 4 was 2.7 , which was categorized as medium level.

Statement number 5 was to find out if the students feel more comfortable when doing offline learning. The results proved that $25 \%$ of the students strongly agreed with the statement, $29 \%$ were agree, $14 \%$ were undecided, $25 \%$ disagreed, and $7 \%$ strongly disagreed. The mean score of statement number 5 was 3.4, which was categorized as medium level.

Statement number 6 was to find out if lecturers give clear instructions during online lectures. The result indicated that $11 \%$ of the students strongly agreed with the statement, $36 \%$ of them were agree, $21 \%$ were undecided, $32 \%$ were disagree, and $0 \%$ strongly disagreed. The mean score of statement number 6 was 3.3, which was categorized as medium level.

Statement number 7 was to find out if lecturers provide sufficient learning resources during online lectures. The results revealed that $11 \%$ of the students strongly agreed with the statement, $39 \%$ of them were agree, $36 \%$ were undecided, $3 \%$ were disagree, and $11 \%$ strongly disagreed. The mean score of statement number 7 was 3.4, which was categorized as medium level.

Statement number 8 was to find out if lecturers give more assignments during online lectures. The results displayed that $16 \%$ of the students strongly agreed with the statement, $40 \%$ of them were agree, $26 \%$ were undecided, $5 \%$ of them were disagree, and $13 \%$ strongly 
disagreed. The mean score of statement number 8 was 3.5 , which was categorized as high level.

Statement number 9 was to find out if the exercise given by a lecturer online is more difficult than usual exercise during offline lectures. The results showed that $11 \%$ of the students strongly agreed with the statement, $39 \%$ of them agreed, $22 \%$ of them undecided, $21 \%$ of them disagreed, and $7 \%$ strongly disagree with the statement. The mean score of statement number 9 was 3.3, which was categorized as medium level.

Statement number 10 was to find out if the course material given during blended learning is more substantial and well conveyed. The results indicated that $0 \%$ of them strongly agreed with the statement, $32 \%$ of them were agree, $61 \%$ were undecided, $3 \%$ were disagree, and $4 \%$ strongly disagreed. The mean score of statement number 10 was 3.2, which was categorized as medium level.

Statement number 11 was to find out if the online lecture always runs beneficially. The results displayed that $4 \%$ of the students strongly agreed with the statement, $46 \%$ of them were agree, $28 \%$ were undecided, $18 \%$ were disagree, and $4 \%$ strongly disagreed. The mean score of statement number 11 was 3.3, which was categorized as medium level.

Statement number 12 was to find out if the students feel more enthusiastic to attend online classes over offline ones. The results indicated that $7 \%$ of the students strongly agreed with the statement, $18 \%$ of them were agree, $25 \%$ were undecided, $36 \%$ were disagree, and $14 \%$ strongly disagreed. The mean score of statement number 12 was 2.7 , which was categorized as medium level.

Statement number 13 was to find out if the students feel more motivated while studying online. The results showed that $0 \%$ of the students strongly agreed with the statement, $14 \%$ of them were moderately agree, $39 \%$ were undecided, $36 \%$ were disagree, and $11 \%$ strongly disagreed. The mean score of statement number 14 was 2.7 which categorized as medium level.

Statement number 14 was to find out if the students feel like blended learning allows them to practice pronunciation more than conventional method (offline class) does. The results revealed that $4 \%$ of the students strongly agreed with the statement, $32 \%$ of them were agree, $36 \%$ were undecided, $14 \%$ were disagree, and $14 \%$ strongly disagreed. The mean score of statement number 14 was 3 , which was categorized as medium level.

Statement number 15 was to find out if blended learning makes the students better at managing their time. The results proved that $7 \%$ of the students strongly agreed with the statement, $46 \%$ of them were agree, $36 \%$ were undecided, $4 \%$ of them were disagree, and $7 \%$ were strongly disagree. The mean score of statement number 15 was 3.5 , which was categorized as high level.

Statement number 16 was to know if students feel satisfied with the blended learning. The results showed that $0 \%$ of them strongly agreed with the statement, $46 \%$ of them were agree, $36 \%$ were undecided, $14 \%$ were disagree, and $4 \%$ strongly disagreed. The mean score of the statement number 16 was 3.3, which was categorized as medium level.

Statement 17 was about if the students feel that their pronunciation skill improves while studying at home. The results indicated that $11 \%$ of the students strongly agreed with the 
statement, $14 \%$ of them were agree, $39 \%$ were undecided, $32 \%$ were disagree, and $4 \%$ strongly disagreed. The mean score of statement number 17 was 3.0 , which was categorized as medium level.

Statement 18 was about if students feel that pronunciation is a subject that they can learn independently. The results proved that $14 \%$ of the students strongly agreed with the statement, $43 \%$ of them were agree, $14 \%$ were undecided, $22 \%$ of them were disagree, and $7 \%$ strongly disagreed. The mean score of statement number 18 was 3.4 , which was categorized as medium level.

Statement 19 was about if students feel that blended learning is more effective than conventional lectures. The results presented that $7 \%$ of the students strongly agreed with the statement, $32 \%$ of them were agree, $39 \%$ were undecided, $18 \%$ were disagree, and $4 \%$ strongly disagreed. The mean score of statement number 16 was 3.2, which was categorized as medium level.

Statement 20 was about if students prefer the blended learning model over conventional lectures. The results indicated that $7 \%$ of the students strongly agreed with the statement, $18 \%$ of them were agree, $46 \%$ were undecided, $25 \%$ were disagree, and only $4 \%$ were strongly disagree. The mean score of statement number 20 was 3.0, which was categorized as medium level.

\section{Interview Results}

When the interview was being conducted, the students expressed a variety of responses regarding their perception of blended learning in Pronunciation classroom, which were described in detail as follows.

The first question was about what students like most in terms of pronunciation teaching materials. The answers received were varied. $14.3 \%$ of the students preferred to practice their pronunciation more, $21.4 \%$ of the students preferred to have more fun and engaging learning materials, $14.3 \%$ of the students preferred to have more interaction with fellow students or with the lecturer, and $50 \%$ of the students had random answers.

The second question was that the researchers asked what students do not like most in terms of teaching materials. There were also various answers which can be categorized into four main answers. $25 \%$ of the students do not like materials that are difficult, and not explained well by lecturer. In which all those three answers were mentioned by at least $3.6 \%$ of students respectively. Meanwhile, $60.1 \%$ of the students had totally different answers.

Next, the researchers asked what students like most in terms of the learning process. $7.1 \%$ of the students preferred to know some new words, $21.4 \%$ of them preferred to practice their pronunciation more, $10.7 \%$ of the students preferred to have a lecturer whose teaching style is engaging and impactful, $14.3 \%$ of the students liked to discuss with friends and $7.1 \%$ of the students to have lessons which are easy to be understood. The rest was $39.4 \%$ of the students had extremely diverse answers.

Question number four, the researchers asked what students do not like most in terms of the learning process. $3.6 \%$ of the students did not like to read a lot, $3.6 \%$ of the students did not like to have boring learning process, $7.1 \%$ of the students did not like to have online classes, $17.9 \%$ of the students did not like to find something difficult to understand, $7,1 \%$ of the 
students did not like to have too many assignments, $7,1 \%$ of the students did not like to practice and another $7.1 \%$ of the students did not like to see a lecturer who cannot explain the material clearly. The rest was $46.5 \%$ of the students had totally different answers.

The last question, the researchers asked what type of online class that will make students interested to get involved. Again, the answers were so varied. $7.1 \%$ of the students preferred class that do practices via Zoom or similar applications, $10.7 \%$ of the students preferred class that has good topics to be discussed, and is interacting students to be actively engaged, $35.7 \%$ of the students preferred effective class that does not only consist of assignments and homework, $3.6 \%$ of the students respectively preferred class where both lecturer and students have the same energy to build conversation and class that is impactful for all parties involved, and $7.1 \%$ of the students preferred class that employs certain teaching methods. The rest was $35.8 \%$ of the students have wide variety of preference, in which some of those were irrelevant with the question.

In addition to distributing questionnaires and doing interviews, researchers also observed the teaching and learning activities. Therefore, the researchers included screenshots of the pronunciation learning process as the supporting data.
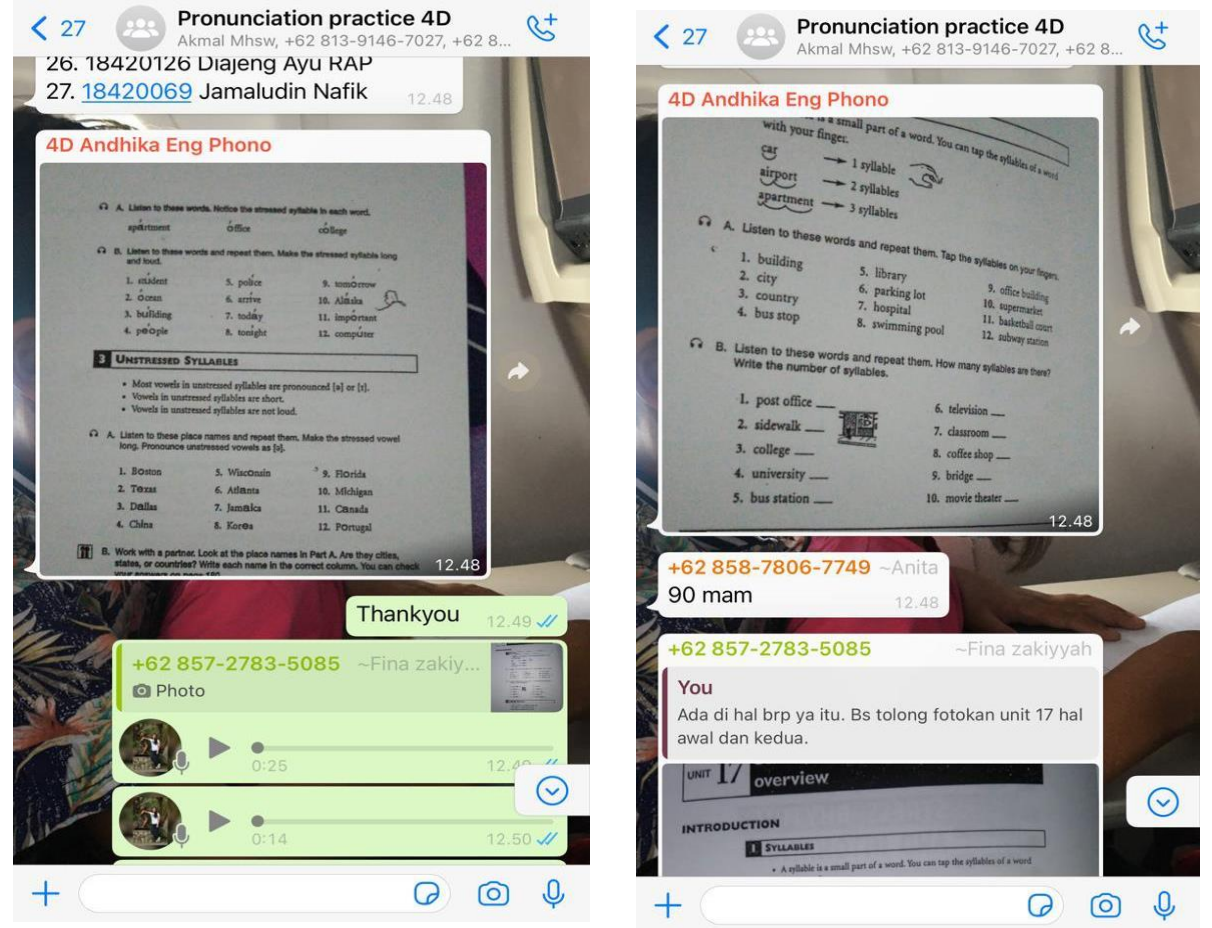

Figure 1 The Examples of Learning Process through Voice Note in WhatsApp Group

Based on the class observation, it was found that the learning process that was being conducted online through Voice Note in WhatsApp Group which was used as one of media in delivering the output of the students' sound production. In this process, the lecturer stated that it was difficult when the students produced incorrect sound and she wanted to give some clues or instructions, so they can use their speech organs in a correct way then they can produce the appropriate sounds as instructed. 


\section{Discussion}

Based on the results of the research presented previously, the researchers discuss the results of the questionnaire and interview by grouping the responses into four categories, which are explained below.

Based on the mean score calculation, the results showed that item one to item five was majority categorized as medium level and only item three was in the high-level category. It means, students mostly had neutral response toward the situations being asked. The number of students who have already understood the concept of blended learning is rather equal with those who have not. On the other hand, there is positive response from students in terms of the discipline, which means it can be ascertained that the respondents were disciplined students. In sum, it can be concluded that even though the students have understood the blended learning model, and most of them have independent and disciplined characteristics in learning, but they still prefer face-to-face or offline lectures. This could be partly because students felt uncomfortable if they rarely visit the campus, which is possibly related to student burnout while studying at home for a long period of time.

Next, item six to item ten which relate to students' perceptions of the teaching process that occurred during the implementation of blended learning. Their responses to statements presented were at an intermediate level. From the results that have been presented in the previous section, it was known that most students felt that the lecturer had provided clear instructions during online lectures. However, not a few students were confused and also felt that the lecturer had not given clear instructions. The students felt that the lecturer had provided sufficient learning resources during online lectures in terms of learning resources. Students also felt that during online lectures, the lecturers gave difficult, a greater number of assignments. However, the majority of students still had not determined whether the lecture material provided during blended learning was more substantial than the ones during the offline lectures.

Based on the mean score calculation, the results showed that item eleven to item fifteen were majority categorized as medium level, and only item number fifteen is in the high-level category. It means student responses to statements presented are at the intermediate level. There is a positive response from students in terms of time management, which means it can be ascertained that the blended learning model makes students smarter at managing time. Therefore, it can be concluded that even though it was conducive, students did not feel enthusiastic and motivated during online lectures. However, students felt that they could practice pronunciation better at managing time during online lectures.

The last group is about students' perception of blended learning itself. Students were basically satisfied with blended learning. However, students felt that their pronunciation skill did not really improve while studying at home. However, this result is clashing with the result of statement number fourteen in which most students agreed that blended learning allows them to practice pronunciation more than conventional method (offline class) does. Also, it was found that majority of students moderately felt that pronunciation was a subject that they could learn independently. From this finding, it can be assumed that the implementation of blended learning was not a problem for the majority of the student, since blended learning required students' good autonomic learning ability.

Furthermore, the results showed that item sixteen to item twenty, this group of result is categorized as medium level. That is, students' responses to statements presented were 
satisfied with the blended learning. A balanced percentage of students thought that blended learning was more effective than conventional lectures and those who undecided yet. The researchers assumed that the different types of students caused this; students who were used to study independently, students who undecided, and students who were not accustomed to learning independently. The researchers felt that students' independence in learning also affects the effectiveness of the blended learning model, as discussed in the previous chapter in the background section. At last, students were yet able to decide whether they preferred blended learning or conventional lecture, for the majority of students undecided. Although, it was likely that students preferred conventional lecture more than online ones. This result can be caused by the recently-implemented blended learning, which students were still not familiar with, compared to the conventional model implementation.

The interview findings were used to support the data, it is known that $21.4 \%$ of the students like the fun and engaging teaching materials, which include pronunciation practices as their preferred material. On the other hand, $25 \%$ of the students do not like teaching materials that are difficult and not explained well by the lecturer. Furthermore, regarding to the learning process, there are some things that students like the most, such as knowing some new words, practicing pronunciation, having lecturer whose teaching style is engaging and impactful, being able to discuss with friends and having lessons which are easy to be understood. In contrast, with what students like, there are also some things that students do not like most in terms of the learning process, such as the requirement to read a lot, the boring learning process, online classes in general, difficult materials, too many assignments and practices and also the lecturers who cannot explain the material clearly.

Finally, students also explained types of online class that will make them interested to get involved, such as the class which do practices via Zoom or similar applications; the class where both lecturer and students have same energy to build conversation; the class which is impactful for all parties involved; the class that has good topics to be discuss, and is interacting students to be actively engaged; the effective class which does not only consist of assignments and homework; and the class which employs certain teaching methods.

\section{CONCLUSION}

The discussion from the prior section was to be summarized to achieve the purpose of the study. The summaries may be concluded as follows; the result of the research indicates that students' perception toward blended learning in Pronunciation classroom is intermediate. Seventeen questionnaire items were in medium levels and three questionnaire items were in high level. The students were satisfied with blended learning implementation in Pronunciation classroom, which was conducted through WhatsApp Group as one of the media used. However, students still prefer offline learning over blended learning. Meanwhile, the students preferred online classes which were balanced in term of assignment-giving and learning material. Too many assignments with less materials only burden the students. The lecturer's ability in handling the class also interested students in engaging the online classes more.

\section{REFERENCES}

Akyol, Z., \& Garrison, D. R. (2011). Understanding cognitive presence in an online and blended community of inquiry: Assessing outcomes and processes for deep 
approaches to learning. British Journal of Educational Technology, 42(2), 233-250. doi:10.1111/j.1467-8535.2009.01029.x

Albiladi, W. S., \& Alshareef, K. K. (2019). Blended learning in English teaching and learning: A review of the current literature. Journal of Language Teaching and Research, 10(2), 232. DOI:10.17507/jltr.1002.03

Ardini, S. N., Lestari, M. Y. W., \& Ouwpoly, N. L. (2016). Error analysis of phonetic fossilization uttered by English department students University of PGRI Semarang. Lensa: Kajian Kebahasaan, Kesusastraan, dan Budaya, Vol. 6(1), 1-8.

Ary, D. (2010). Introduction to research in education. Canada: Wadsworth.

Bonk, C. J., \& Graham, C. R. (2012). The handbook of blended learning: Global perspectives, local designs. John Wiley \& Sons.

Bueno-Alastuey, M. C., \& López Pérez, M. V. (2014). Evaluation of a blended learning language course: Students' perceptions of appropriateness for the development of skills and language areas. Computer Assisted Language Learning, 27(6), 509-527.

Gecer, A. (2013). Lecturer-student communication in blended learning environments. Educational Sciences: Theory and Practice, 13(1), 362-367.

Gilakjani, A. P. (2012). A Study of factors affecting EFL learners' English pronunciation learning and strategies for instruction. International Journal of Humanities and Social Science, 1(1), 119-128.

Graham, C. R. (2013). Emerging practice and research in blended learning. In M. G. Moore (Ed.), Handbook of distance education, (3rd ed., pp. 333-350). New York: Routledge.

Harvey, L., \& Knight, P. T. (1996). Transforming higher education. Open University Press, Taylor \& Francis, 1900 Frost Road, Suite 101, Bristol, PA 19007-1598.

Kelly, G. (2000). How to teach pronunciation. London: Pearson Education Limited.

Kothari, C. R. (2004). Research methodology research \& techniques. Jaipur: New Age International, Ltd. Publishers.

Putra, Ilham (2020). Nadiem minta semua bersabar dengan belajar daring. https://www.medcom.id/pendidikan/news-pendidikan/3NOGGxpN-nadiemminta-semua-bersabar-dengan-belajar-daring. Accessed on July 15, 2020 at 22.44 WIB

Senowarsito \& Ardini, S. N. (2019). Phonological fossilization of EFL learners: The interference of phonological and orthographic system of L1 Javanese. $3 L$ The Southeast Asian Journal of English Language Studies, 2, 74-85. https://doi.org/10.17576/31-2019-2502-06

Su'adah, A. (2015). Students' Perception toward the use of Edmodo in teaching and learning process at One State University in Jambi. Available at 
http://repository.fkip.unja.ac.id/file?i=KHOQH1nzQ_uUXCLEgsNxQ8rtngk58w5o bbZBCoAGrA0 (accessed on Friday $5^{\text {th }}$ April 2019)

Sukardi. (2003). Metodologi penelitian pendidikan kompetensi dan prakteknya. Jakarta: Bumi Aksara. 